\title{
КРИТЕРИИ КАЧЕСТВА ЮРИДИЧЕСКИХ УСЛУГ, ПРЕДОСТАВЛЯЕМЫХ ГРАЖДАНАМ
}

\author{
Н. В. Полякова, В. В. Поляков, Ю. О. Баранова \\ Байкальский государственный университет, г. Иркутск, Российская Федерация
}

\author{
Информация о статье \\ Дата поступления \\ 4 сентября 2017 г. \\ Дата принятия к печати \\ 20 ноября 2017 г. \\ Дата онлайн-размещения \\ 27 ноября 2017 г.

\section{Ключевые слова} \\ Юридическая услуга; качество \\ услуг; критерии качества \\ услуг; стандарты качества; \\ обслуживание клиентов; \\ менеджмент услуг
}

\begin{abstract}
Аннотация
В статье содержится литературный обзор представлений о качестве юридических услуг авторов - специалистов в области менеджмента услуг и услуг правового содержания, предоставляемых гражданам. Констатируется слабая теоретическая разработанность проблемы оценки качества юридических услуг как одних из самых сложных, а также ее высокая актуальность для практической деятельности юридических организаций и развития российского рынка правовых услуг. Выделены стороны, заинтересованные в обеспечении качества этих услуг: государство; профессиональные юридические сообщества, объединяющие услугопроизводителей; граждане как реальные и потенциальные услугополучатели. Рассмотрены основания для разработки критериев оценки качества отдельных составляющих юридической услуги. Сделана попытка сформировать логичную совокупность критериев качества юридических услуг, состоящую из трех групп: профессиональные критерии; процедурные критерии; критерии с точки зрения потребителей. Кратко освещен зарубежный опыт решения проблемы качества юридических услуг.
\end{abstract}

\section{CRITERIA FOR THE QUALITY OF LEGAL SERVICES PROVIDED TO CITIZENS}

\author{
Nina V. Polyakova, Vladimir V. Polyakov, J ulia O. Baranova \\ Baikal State University, Irkutsk, Russian Federation
}

\section{Article info}

Received

September 4, 2017

Accepted

November 20, 2017

Available online

November 27, 2017

\section{Keywords}

Legal service; quality of services: criteria of quality of services; quality standards; customer service; management services

\begin{abstract}
The article presents a review of literature on conceptions of the quality of legal services provided to citizens as seen by the authors-experts in the field of service management and legal services. The authors find weak theoretical development of the problem of assessing the quality of legal services as one of the most difficult, as well as its high relevance for practical activities of legal organizations and the development of the Russian market of legal services. The parties interested in ensuring the quality of these services are as follows: the state; professional legal communities that unite service providers; citizens as real and potential customers. The authors examined the grounds for the development of criteria of assessing the quality of individual components of legal services. They have also attempted to form a logical set of criteria of the quality of legal services, consisting of three groups: professional criteria; procedural criteria; criteria from the point of view of consumers. The international experience of solving the problem of quality of legal services has also been briefly described.
\end{abstract}

Потребление услуг стало важным явлением экономики развитых стран. Темпы роста мирового рынка услуг в два раза превышают темпы роста торговли товарами. Сорормировалась тенденция к расширению видов обслуживания. Увеличивается количество предоставляемых услуг, появляются новые их виды, вытесняющие традиционные. Потребление услуг начинает преобладать над потреблением товаров. В результате между фирмами, предоставляющими различные услуги населению, возникает конкуренция, обострение которой наблюдается повсеместно, и наиболее важным конку- 
рентным преимуществом в сложившихся условиях становится качество услуг.

Качественно предоставленная услуга и, как следствие, удовлетворенность ее потребителя содействуют появлению положительных отзывов и рекомендаций о фирме, притоку новых клиентов, снижению затрат на их привлечение, потребители становятся менее подверженными влиянию ценового фактора, а также конкурентов фрирмы. Поэтому на современном этапе экономического развития качество услуг и качество обслуживания приобретают все большее значение.

Качество услуг как самостоятельная категория начало изучаться с середины 1970-х гг. на этапе перехода к экономике услуг. Так как развитие данной категории продолжается, в научном обиходе имеется несколько десятков определений категории «качество услуги», что затрудняет ее практическое использование.

Понятие качества юридических услуг. Одно из первых определений качества услуги дано В. Цейтамлем в 1988 г.: «Качество услуги - это суждение потребителя о совершенстве или превосходстве услуги» [1, с. 84].

Качество услуги определяется также как сравнение ожиданий потребителей с реальными результатами деятельности производителя услуги. Здесь качество услуги понимается как соотношение ожиданий и восприятия оказанной услуги, когда услуга соответствует требованиям клиента. Ведущими представителями этого направления являются К. Гренроос, А. Парасураман, В. Цейтамль и Л. Берри, Э. Гуммессон, Дж. Хейвуд-Фармер, А. Гобадиан, С. Спеллер, М. Джонс [там же, с. 91]. Данный подход начал фрормироваться еще в 1980-е гг., поэтому его можно считать предшественником современного понимания качества услуги как сравнительной категории, основанной на соответствии услуги требованиям потребителей.

В начале 1990-х гг. Дж. Кронин и С. Тейлор указали на то, что не всегда клиент приобретает услугу наилучшего качества. Он принимает решение о покупке на основе представления о ценности услуги, которая стала объектом изучения нового направления [2, с. 219]. Первоначально ценность услуги рассматривалась как результат сравнения тех выгод и положительного опыта, которые приобрел клиент, и затрат, которые ему пришлось понести. В ходе длительных исследований эти авторы пришли к выводу, что качество услуги является формой по- требительского отношения к ней, и поэтому оно должно оцениваться исключительно путем измерения восприятия клиентом услуги и ее отдельных свойств.

С точки зрения потребителя, под качеством услуги подразумевается своеобразная форма мнения, результат сравнения ожиданий качества до потребления услуги с непосредственным восприятием качества в момент и после ее потребления.

Более глубокое изучение ощущений потребителя предприняли В. Цейтамль, Л. Берри и А. Парасураман. Они выделили три уровня обслуживания клиентов: желаемый, адекватный и предсказанный [3, с. 185]. При желаемом уровне обслуживания клиент надеется получить такое качество, которое будет соответствовать его личным потребностям. Но это не всегда достижимо, и многие клиенты это понимают, в результате возникает адекватный уровень обслуживания. На данном уровне потребитель устанавливает для себя тот минимум обслуживания, который не вызывал бы явного неудовлетворения от качества услуги. У потребителей вырабатываются ожидания относительно качества услуги, основанные на прошлом опыте, цене, которую они платили, и на других фракторах. Когда клиент оценивает качество услуг, он сравнивает некоторые фрактические значения параметров оценки качества с ожидаемыми им величинами этих параметров. Если ожидания совпадают, качество услуг признаётся им адекватным. Предсказанный уровень обслуживания - это уровень, который потребители ожидают получить. Он зависит от того, какой уровень обслуживания в той или иной ситуации клиент посчитал для себя адекватным.

Таким образом, очевидно, что качество услуг является весьма сложным понятием, которое нельзя рассматривать единообразно, используя стандартные параметры для всех видов услуг. Необходимо учитывать социально-правовую категорию услуг, степень их индивидуальности и субъективности, разнородность видов самих услуг, а также нередкое отсутствие в них конечного материального результата. В каждом отдельном случае к понятию качества услуги нужно подходить индивидуализированно с учетом специфики услуги, ожиданий заказчика, обязательных нормативов, а также возможностей исполнителя и способа осуществления им соответствующей деятельности.

Юридическая услуга - яркий пример сложной, профессиональной услуги. Ее 
можно отнести к одной из пяти категорий маркетинговых предложений, описанных Ф. Котлером, а именно к «чистой» услуге, которая обладает предполагаемыми, или доверительными, характеристиками. Такие характеристики сложно оценить даже после потребления услуги [3, с. 44].

Юридические услуги обладают высокой степенью неосязаемости и могут быть расположены на шкале В. Сассера, Р. Ользена и Д. Вайкофффа в области высокой степени неосязаемых элементов наряду с такими услугами, как управление инвестициями или психотерапия [там же, с. 45].

К. Лавлок относит юридические услуги к категории сложных, при предоставлении которых осуществляются неосязаемые действия с неосязаемыми активами [там же, с. 53]. Применительно к юридическим услугам под неосязаемыми активами понимаются права, получение которых гарантировано каждому гражданину от рождения основными законами государства.

Обратимся к литературе, посвященной качеству юридических услуг. Проблему качества оказания юридических услуг рассматривали многие авторы: Е. М. Берлин [4, с. 26], М. Ю. Барщевский [5, с. 248], М. В. Кратенко [6, с. 119], С. Н. Гаврилов $[7$, c. 20] и др. Выделен целый ряд критериев качества отдельных видов юридических услуг: правильность оформления жалоб и обращений, непротиворечивость и ясность договоров, актуальность консультаций и иные. Было определено, что качество юридических услуг связано с личными качествами юриста (профессионализмом, добросовестностью). С. Н. Гаврилов высказал мнение, что критерии качества юридической услуги нужно искать в описании самого процесса ее оказания. Однако общего подхода к пониманию качества оказания юридических услуг найдено не было.

В литературе также высказывается мнение о том, что смысл надлежащего качества услуги нужно искать в полезных свойствах ее результата. С этой точки зрения главным критерием качества услуги может выступать удовлетворенность клиента. Это лежащий на поверхности и, казалось бы, самый верный способ оценки качества услуги. Однако при более внимательном рассмотрении обнаруживается несостоятельность такого подхода. Классический пример: адвокат сделал все, что было возможно по данному делу, но результат оказался не тот, который ожидал клиент. Помощь была некачественной? Например, адвокат выступал на стороне истца. Иск удовлетворили частично или в его удовлетворении отказали. Помощь была некачественной? Такой категоричный вывод является неправильным.

При оценке качества юридических услуг нельзя ориентироваться исключительно на мнение клиента как потребителя. «Клиент всегда прав!» - лозунг, непригодный для сореры правовых услуг. Результат по делу зависит от множества фракторов. Полагать, что способность адвоката добиться желаемого для клиента результата предопределена лишь знаниями, навыками, умениями, опытом, способностями адвоката, ошибочно. Значит, результат не может являться единственным и главным критерием качества оказываемой правовой услуги. По нашему мнению, прав М. В. Кратенко, отметивший, что конструкция «качество услуги» довольно условна. Оперируя данным термином, необходимо подразумевать под ним оценку самого процесса оказания услуги и условий ее потребления, а не результата работы юриста [6, с. 121].

Более того, нужно считать нарушением требований к качеству правовых услуг указание на стопроцентную вероятность выигрыша дела или достижения другого правового результата, а также информирование клиента о том, что юрист гарантирует достижение поставленной цели при любых обстоятельствах. Подобные утверждения следует квалифицировать как намеренное введение в заблуждение, поскольку общеизвестным является то, что выигрыш дела зависит не только от содержания соответствующих правовых норм, но и от наличия или отсутствия у клиента возможности для сбора доказательств, обосновывающих его позицию, а также от деятельности конкретного правоприменителя, т. е. от его квалификации, наличия или отсутствия у него заинтересованности в исходе дела и т. д. Договор оказания правовых услуг как разновидность договора возмездного оказания услуг не может содержать такое условие, как гарантирование положительного результата. Юрист может предоставить клиенту только правовое заключение относительно того, нарушены его права или нет, и на основании этого он также может оговорить возможность успешного разрешения дела для клиента в зависимости от конкретных фракторов. В случае проигрыша дела вознаграждение исполнителя не подлежит возврату, поскольку правовая услуга потребляется в процессе ее оказания. Подготовка процессуальных документов, консультации, 
представительство интересов в суде и есть предмет правовых услуг, за исполнение которого отвечает производитель услуги.

Гарантирование выигрышности дела своего рода обман клиента. При оказании правовых услуг присутствует ряд непредвиденных фракторов, влияющих на конечный результат оказываемых услуг, а именно: действия другой стороны в споре, субъективные убеждения судьи, некомпетентность должностных лиц органов, в которых происходит защита прав клиента, и т.д. Оценить все возможные факторы, влияющие на положительный исход дела, невозможно, а потому и заверение клиента в гарантированном успешном решении его вопроса является нарушением этики юриста.

Всё, что может гарантировать юрист, это качественное оформление всех процессуальных документов и профессиональное представительство интересов. При оказании правовых услуг фирма не может отвечать за действия третьих лиц, будь то суд или другие органы, и, следовательно, честный юрист не может гарантировать определенный результат предоставления юридических услуг.

Значит, можно гарантировать только профессиональное добросовестное выполнение всех процессов оказания услуги. Юрист может отвечать лишь за свои действия по ее оказанию. Например, при оказании консультационных правовых услуг он может обеспечить достоверность, полноту, своевременность предоставляемых сведений, но не может гарантировать полезный эфффект от использования результата услуги клиентом, в частности то, насколько удачно последний воспользуется полученной информацией. Ведь достижение полезного эффректа от услуги зависит и от того, как происходит ее потребление, и от того, имеются ли объективные условия для достижения положительного для клиента результата. Таким образом, достижение полезного эфрфекта от услуги обусловливается качествами и действиями не только исполнителя, но и потребителя услуги, а также другими объективными обстоятельствами, например действиями третьих лиц.

Действительно, не всё в разрешении правовой проблемы зависит от юриста. Свою лепту вносят и судьи, и иные должностные лица, вовлеченные в этот процесс. Не стоит забывать и о самом клиенте, который может сообщить юристу неполную либо недостоверную информацию, основываясь на которой юрист может сделать ошибки. Также клиент может не выполнить или не полностью выполнить инструкции юриста, что повлечет за собой неблагоприятный исход дела. При этом вины юриста в произошедшем не будет. Таким образом, неудовлетворительный результат не обязательно является следствием ненадлежащего качества работы юриста.

Проигранный спор не может однозначно свидетельствовать о том, что клиенту причинены убытки именно вследствие недобросовестной работы юриста. Порой самое качественное оказание юридических услуг может привести к неудовлетворительным результатам рассмотрения дела в суде.

Для того чтобы оценить качество работы юриста, следует оценивать процесс оказания юридической услуги во всей полноте, а именно каким образом было выстроено взаимодействие с клиентом, составлялись ли необходимые документы, проходило ли участие в правовых процедурах, как собиралась и проверялась информация, формировалась база доказательств. Требуется выяснить, выполнил ли юрист все действия, которые было бы разумно предпринять для разрешения проблемы клиента исходя из обстоятельств конкретного дела, действующего законодательства, сложившейся правоприменительной практики с соблюдением требований профессиональной этики.

Процесс оказания юридических услуг должен осуществляться при тесном взаимодействии юриста и клиента. От правильно выстроенного взаимодействия с клиентом зависит, насколько полной и достоверной будет информация о деле, а также насколько тщательно клиент будет следовать советам юриста. Это в немалой степени может повлиять на исход дела. Следовательно, можно сделать вывод о том, что надлежащий характер взаимодействия с клиентом является еще одной стороной качества юридических услуг.

Если рассмотреть судебное представительство интересов клиента, то качественное оказание услуг может предусматривать детальный правовой анализ ситуации с учетом судебной практики, досудебную подготовку дела, своевременное совершение процессуальных действий в соответствии с установленными правилами, личное участие представителя в судебных заседаниях, своевременное представление суду всех необходимых доказательств, а в случае необходимости - заявление ходатайств об их истребовании или обеспечении, грамотное и последовательное изложение позиции клиента в письменной или устной форме, 
участие в судебных прениях и заявление обоснованных возражений против аргументов, выдвигаемых другой стороной, и т. д.

Заключая договор на судебное представительство, клиент рассчитывает на полный или частичный выигрыш своего дела. Несмотря на это, вынесение судом или другим органом решения, не соответствующего ожидаемому клиентом результату, является основанием для привлечения юриста к ответственности за некачественное оказание правовых услуг только в том случае, когда это стало следствием нарушения требований, указанных в договоре, а в случае их отсутствия - требований, обычно предъявляемых к правовым услугам.

Формирование критериев качества юридических услуг. Исходя из вышеизложенного, предлагаем рассматривать совокупность критериев качества юридических услуг, объединенных в три группы:

- профессиональные критерии;

- процедурные критерии;

- критерии с точки зрения клиентов.

Профессиональные критерии носят объективный характер, поскольку их сравнительно легко можно оценить, подтвердить их наличие или отсутствие. В этих критериях отражены интересы общества, так как государство считает необходимым поддержание и воспроизводство профессиональных кадров, с помощью которых функционирует российская правовая система.

Если для юристов такие требования носят рекомендательный характер, то для адвокатов существуют обязательные профессиональные требования, установленные законодательством. Например, в соответствии с Федеральным законом «Об адвокатской деятельности и адвокатуре в Российской Федерации» от 31 мая 2002 г. № 63-Ф3 адвокат должен иметь высшее юридическое образование, статус адвоката, стаж работы по юридической специальности не менее двух лет либо пройти стажировку в адвокатском образовании от одного года до двух лет и сдать квалификационный экзамен. Адвокат должен постоянно совершенствовать свои знания самостоятельно и повышать свой профессиональный уровень в порядке, установленном органами адвокатского самоуправления. Не могут претендовать на приобретение статуса адвоката люди, которые признаны недееспособными или ограниченно дееспособными и имеют непогашенную или неснятую судимость за совершение умышленного преступления.
Процедурные критерии носят частично объективный и частично субъективный характер, так как в них воплощаются морально-этические нормы, которые формулируют профессиональные юридические сообщества и организации. Профессиональные сообщества заинтересованы в том, чтобы юристы следовали критериям качества осуществления юридических процедур, препятствуя недобросовестному оказанию услуг отдельными юристами, поскольку некачественная работа последних снижает востребованность юридических услуг. Эти критерии частично отражены в законодательных документах, регламентирующих деятельность адвокатов, а также в правилах профессиональных юридических объединений и организаций. Критерии данной группы трудно поддаются оценке.

В процессе оказания юридической услуги юрист должен соблюдать конфиденциальность в отношении всей информации, предоставленной ему клиентом или полученной в ходе предоставления юридических услуг, и эти обязательства не ограничены во времени. Кроме того, юрист не может гарантировать положительный результат решения проблемы клиента, так как стопроцентная вероятность выигрыша дела или достижения иного правового результата невозможна. Подобные утверждения следует квалифицировать как намеренное введение в заблуждение.

Далее, юрист не должен принимать поручение на ведение дела клиента, когда для этого нет оснований. Например, клиент просит вчинить иск, тождественный уже рассмотренному делу, о чем у юриста уже имеются сведения; клиент просит подать апелляционную жалобу, но аналогичная жалоба уже рассмотрена. Кроме того, услуга должна быть оказана в соответствии с законодательными нормами. Важно также, чтобы юрист предлагал клиенту возможные варианты решения проблемы. Он должен информировать клиента обо всех доступных правовых способах решения его проблемы, а также акцентировать внимание на достоинствах каждого способа и рисках, связанных с выбором того или иного способа, перечислить финансовые и временные издержки по каждому предлагаемому варианту и правовые последствия выбора клиента.

Если для юристов такие требования носят рекомендательный характер, то для адвокатов существуют обязательные профессиональные требования, установленные 
законодательством. Прежде всего, адвокат должен честно, разумно, добросовестно, квалифицированно, принципиально и своевременно исполнять свои обязанности, активно защищать права, свободы и интересы доверителей всеми не запрещенными законодательством средствами, руководствуясь Федеральном законом «Об адвокатской деятельности и адвокатуре в Российской Федерации» и Кодексом профессиональной этики адвоката (принят первым Всероссийским съездом адвокатов 31 января 2003 г.). Федеральный закон «О бесплатной юридической помощи в Российской Федерации» от 21 ноября 2011 г. № 324-Ф3 регулирует соответствующий аспект адвокатской деятельности.

Во-вторых, адвокат должен уважать права, честь и достоинство лиц, обратившихся к нему за оказанием юридической помощи, доверителей, коллег и других лиц, придерживаться манеры поведения и стиля одежды, соответствующих деловому общению. В-третьих, адвокат не вправе давать лицу, обратившемуся за оказанием юридической помощи, или доверителю обещания положительного результата оказываемых услуг. В-четвертых, адвокат не должен принимать поручение, если его исполнение будет препятствовать исполнению другого, ранее принятого поручения. В-пятых, адвокат не должен допускать фамильярных отношений с доверителем. В-шестых, адвокат не вправе использовать информацию, составляющую предмет адвокатской тайны, при работе по делам других клиентов и не вправе подробно рассказывать о работе по делу в кругу семьи или друзей, не вправе использовать информацию, составляющую предмет адвокатской тайны, в личных целях.

Кроме требований для адвокатов, имеются другие нормативные документы, декларирующие требования к качеству юридических услуг, например ГОСТ Р 52142-2003 «Социальное обслуживание населения. Качество социальных услуг. Общие положения» (принят постановлением Госстандарта РФ от 24 ноября 2003 г. № 326-ст) и ГОСТ Р 53061-2008 «Социальное обслуживание населения. Контроль качества социальных услуг детям» [8, с. 26]. В указанных документах определены такие требования к качеству юридических услуг, как формирование у клиентов правильного представления о путях защиты их прав, юридически грамотное изложение жалобы, разъяснение содержания составленных документов, своевременность решения проблем, личное содействие и представительство в суде.

Сообщества юристов без участия государства разрабатывают и внедряют собственные критерии качества и публикуют их. Следует отметить удачный опыт разработки критериев деятельности юридических фирм уральским некоммерческим партнерством «Объединение участников рынка правовых услуг «Национальная правовая палата» [9, с. 48]. Предложенный данной организацией документ включает в себя три составляющие: «Квалификация лиц, оказывающих юридические услуги», «Дисциплинарные процедуры», «Принятие поручений в системе отношений с клиентами». В нем, например, указана необходимость наличия помещения и оборудования, которые обеспечат сохранность документов и конфиденциальность общения с клиентом, обязательность процедуры письменного оформления договора на предоставление юридических услуг и др.

Примером разработки критериев качества работы юристов по отдельным категориям дел является документ адвокатской палаты Санкт-Петербурга, который регламентирует деятельность юриста по делам о недобровольной госпитализации [10, с. 22].

Внутрифирменные наборы критериев качества юридических услуг фрормируются наиболее ответственными и успешными юридическими фирмами. Они преследуют ряд целей: уточнение процесса производства услуги для своих работников, использование критериев для оценки качества их работы, для совершенствования системы стимулирования работников, обучения новых сотрудников и для удовлетворения других потребностей в совершенствовании менеджмента услуг. Документы способствуют повышению конкурентоспособности фирмы на рынке юридических услуг. Публикация критериев позволяет клиенту еще до обращения к юристу оценить должный уровень качества услуги. Более того, обращение в фрирму в этом случае делает клиента более защищенным в своих правах, так как несоблюдение критериев считается нарушением прав потребителя. К сожалению, внутрифирменные критерии качества оказываемых услуг обязательны только для тех субъектов рынка, которые добровольно приняли и соблюдают свои корпоративные стандарты.

Критерии качества юридических услуг с точки зрения клиентов носят явно субъек- 
тивный характер. Если предыдущие группы критериев отражают в большей степени объективные, специализированные требования к качеству этих услуг, то клиентские критерии оценки можно назвать дилетантскими, так как клиент, имеющий профессиональную правовую подготовку, является исключением. Несмотря на дилетантский характер клиентской оценки, данные критерии отражают интересы потребителей, заключающиеся в получении качественных юридических услуг. Недаром первая концепция оценки услуг, т. е. исследование проблем качества услуг, началась с понимания качества услуг как суждений потребителей.

Когда гражданин обращается за получением юридической услуги, он надеется, что юрист предложит выгодное решение его правовой проблемы. Следовательно, один из критериев качества юридических услуг - правильно составленные документы, корректность советов и действий, осуществляемых в интересах клиента. Надлежащее качество юридических услуг означает, что советы, данные юристом во время консультации, соответствуют действующему законодательству и правоприменительной практике. Однако одной правовой корректности мало для того, чтобы говорить о качественно оказанной юридической услуге. Ведь в отличие от правового инфрормирования юридическая услуга подразумевает разра- ботку и реализацию поэтапного алгоритма решения правовой проблемы.

При оценке качества юридической услуги необходимо уделить внимание такому критерию, как оперативность. Если время выполнения услуги велико, то, возможно, помощь юриста опоздает и будет неактуальна.

Также юристу не следует оказывать на клиента психологическое давление, склоняя его к выбору способа решения проблемы. Между юристом и клиентом должны установиться доверительные отношения. Доверие клиента является весьма важным фрактором успеха. Юрист по отношению к клиенту должен проявить вежливость в общении и добросовестность в выяснении обстоятельств дела. Предложенные варианты разрешения проблемы клиента должны быть донесены до него доступным языком. Для пояснения важности критерия «честное отношение к клиенту" при изложении возможных результатов работы и отдаленных последствий достигнутого результата можно привести пример правовой проблемы лишения прав на отцовство. Если женщина решила лишить родительских прав отца своего ребенка, то юрист должен дать подробную информацию о положительных и негативных последствиях такого решения.

Совокупность критериев качества юридических услуг по выделенным выше группам представлена в таблице.

\section{Группы критериев оценки качества юридических услуг, предоставляемых гражданам}

\begin{tabular}{|c|c|c|}
\hline $\begin{array}{c}\text { Профрессиональные } \\
\text { критерии }\end{array}$ & Процедурные критерии & Критерии с точки зрения клиентов \\
\hline $\begin{array}{l}\text { 1. Высшее юридическое } \\
\text { образование. } \\
\text { 2. Опыт работы. } \\
\text { 3. Отсутствие судимости. } \\
\text { 4. Знание информаци- } \\
\text { онно-правовых систем } \\
\text { ( Консультант», «Кодекс» } \\
\text { и др.). } \\
\text { 5. Знание иностранных } \\
\text { языков. } \\
\text { 6. Количество стажировок. } \\
\text { 7. Наличие сертификатов. } \\
\text { 8. Членство в професси- } \\
\text { ональных ассоциациях и } \\
\text { сообществах. } \\
\text { 9. Количество рассмотрен- } \\
\text { ных дел. } \\
\text { 10. Количество выигранных } \\
\text { дел }\end{array}$ & $\begin{array}{l}\text { 1. Соблюдение конфиденциаль- } \\
\text { ности информации, предостав- } \\
\text { ленной клиентом. } \\
\text { 2. Невозможность гаран- } \\
\text { тирования положительного } \\
\text { результата. } \\
\text { 3. Невозможность принятия } \\
\text { поручения на ведение дела } \\
\text { клиента, когда для этого нет } \\
\text { оснований. } \\
\text { 4. Оказание услуг в соответ- } \\
\text { ствии с законодательными } \\
\text { нормами. } \\
\text { 5. Разработка возможных } \\
\text { вариантов решения проблемы } \\
\text { и инфрормирование об этом } \\
\text { клиента }\end{array}$ & $\begin{array}{l}\text { 1. Положительные рекомендации. } \\
\text { 2. Степень оправдания ожиданий } \\
\text { клиента. } \\
\text { 3. Внешний вид офиса. } \\
\text { 4. Внешний вид юриста. } \\
\text { 5. Доступность и культура речи юриста. } \\
\text { 6. Вежливость и приветливость юриста. } \\
\text { 7. Профессиональная уверенность } \\
\text { юриста. } \\
\text { 8. Оперативность работы юриста } \\
\text { (быстрое решение проблемы клиента). } \\
\text { 9. Отзывчивость юриста, желание помочь } \\
\text { в любое время. } \\
\text { 10. Достижение результата, устраиваю- } \\
\text { щего клиента. } \\
\text { 11. Честное отношение к клиенту: } \\
\text { добросовестное изложение возможных } \\
\text { результатов работы и последствий достиг- } \\
\text { нутого результата. } \\
\text { 12. Подробное описание этапов процесса } \\
\text { работы. } \\
\text { 13. Соответствие заявленной и договор- } \\
\text { ной цены на услугу. } \\
\text { 14. Наличие бесплатной консультации, } \\
\text { в том числе по телефрону }\end{array}$ \\
\hline
\end{tabular}


Для получения полной оценки качества юридической услуги следует применять все вышеперечисленные критерии в совокупности.

Зарубежный опыт обеспечения качества юридических услуг. Регламентация сореры юридических услуг в России и в большинстве стран с развитыми правовыми системами существенно различается. Одно из различий - нежелание многих российских юристов вступать в профессиональные сообщества, в том числе адвокатские палаты. Юристы в других странах, как правило, являются частью саморегулируемых профессиональных сообществ. Например, профессиональные ассоциации адвокатов в западных странах обеспечивают поддержание профессиональных стандартов и этических норм, защищают своих членов от преследований и необоснованных ограничений и посягательств, обеспечивают юридическую помощь всем, кто в ней нуждается.

Особую важность приобретает вопрос законодательного регулирования юридических услуг путем установления специальных стандартов. Любой гражданин, которому оказывают юридические услуги, должен иметь возможность удостовериться, что они соответствуют установленным государством критериям.

Важными международно-правовыми документами, которые устанавливают критерии квалифицированной юридической помощи, являются: Международный кодекс этики (принят в 1956 г.), Стандарты независимости сообщества юристов (приняты Международной ассоциацией юристов 7 сентября 1990 г. в Нью-Йорке), Стандарты и критерии для признания профессиональных квалификационных признаков юристов (приняты Международной ассоциацией юристов в июне 2001 г. в Стамбуле), Резолюция в поддержку системы терминологии в отношении юридических услуг в целях международных торговых переговоров (принята Международной ассоциацией юристов в 2003 г. в Сан-Франциско) [11, с. 388].

В развитых правовых государствах, таких как США, Англия или Франция, в рамках лицензирования деятельности по предоставлению платных юридических услуг предъявляются четкие требования: высшее юридическое образование, стаж работы по юридической специальности, получение допуска к юридической практике. Также предусматривается ответственность за осуществление правовой деятельности без лицензии.
В международном праве существует практика, когда юрист несет ответственность за свои профессиональные действия. Например, в США адвокаты несут ответственность, в том числе имущественную, за предоставление клиенту неквалифицированной помощи. Неквалифицированные действия юриста в процессе судебной защиты могут стать основанием для пересмотра или отмены судебного решения в связи с нарушением права гражданина. Одновременно защитник может быть дисквалифицирован навсегда. Введение подобных правил в юридическую деятельность способствует повышению качества юридических услуг [12, с. 48].

В Великобритании установлены следующие критерии оценки качества юридических услуг:

- предоставление доступной информации о предлагаемых услугах и запрет на дискриминацию в оказании услуг;

- возможность переадресации к другим организациям, оказывающим юридические услуги, если этого требуют интересы клиента;

- обеспечение своевременного обучения и повышения квалификации сотрудников юридических фирм;

- конфиденциальность и защита персональных данных клиентов;

- организация системы приема жалоб и отзывов клиентов [13, с. 39].

Кроме государственных органов, функцию обеспечения качества юридических услуг могут брать на себя добровольные объединения. Например, в Нидерландах фонд Viadicte, представляющий собой объединение десяти юридических фирм, осуществляет разработку и соблюдение стандартов качества работы юристов. Некоторые юридические фирмы за рубежом нанимают специалистов, которые осуществляют контроль за обеспечением качества работы юристов [10, с. 20].

Несмотря на различия внутреннего законодательства разных стран, профессиональные сообщества юристов выработали сходные механизмы, способствующие поддержанию высокого уровня качества оказания юридических услуг. К таким механизмам можно отнести: принятие кодексов профессиональной этики и дисциплинарные процедуры, применяемые к лицам, не соблюдающим их положения; специальные программы для обучения молодых юристов; возложение на практикующих юристов обязанности регулярно повышать свою 
квалификацию [14, с. 15]. Соблюдение добровольных стандартов качества правовых услуг осуществляется также с помощью коллегиальных проверок и исследований удовлетворенности клиентов.

Итак, мы можем сделать следующие выводы:

1. Проблема оценки качества юридических услуг является одной из самых сложных и слабо разработанных в теории услуг.

2. В обеспечении качества юридических услуг заинтересованы три стороны: государство (общество), профессиональное сообщество и потребители.

3. Юридические услуги относятся к категории самых сложных. В связи с этим результат предоставления услуги невозможно предсказать, а значит, и гарантировать клиенту положительный исход дела. Следовательно, результат не может быть основным мерилом качества юридической услуги.

4. Для комплексной оценки качества юридических услуг предложена совокупность критериев, состоящая из трех групп: профессиональные критерии; процедурные критерии; критерии с точки зрения потребителей.

5. Высокая актуальность решения проблемы измерения качества юридических услуг заключается в совершенствовании практической деятельности юридических организаций. Это подтверждается большим интересом как российских, так и зарубежных специалистов.

\section{СПИСОК ИСПОЛЬЗОВАННОЙ ЛИТЕРАТУРЫ}

1. Ватолкина Н. Ш. Систематизация подходов к определению категории «качество услуги» / Н. Ш. Ватолкина // Известия Дальневосточного федерального университета. Экономика и управление. 2012. - № 4 (64). - С. 82-93.

2. Абрамов С. С. Оценка качества услуг с учетом позиции потребителя / С. С. Абрамов // Вестник Адыгейского государственного университета. Сер. 5, Экономика. - 2011. - № 1. - С. 215-221.

3. Лавлок К. Маркетинг услуг: персонал, технологии, стратегии / К. Лавлок. - М. : Вильямс, 2005. - 982 с.

4. Берлин Е. М. Законодательное регулирование качества правовых услуг / Е. М. Берлин // Право и экономика. - 2002. - № 5. - С. 23-28.

5. Барщевский М. Ю. Адвокатская этика / М. Ю. Барщевский. - М. : Профробразование, 2000. - 312 с.

6. Кратенко М. В. Доступность юридической помощи и некоторые виды договоров о ее оказании / М. В. Кратенко // Проблемы формирования правового социального государства в современной России : материалы 9-й Всерос. науч.-практ. конф. (Новосибирск, 30 окт. 2013 г.). - Новосибирск : Изд-во НГАУ, 2013. - С. 117-121.

7. Гаврилов С. Н. О качестве юридической помощи в адвокатуре / С. Н. Гаврилов / / Юристъ-Правоведъ. 2007. - № 6. - C. 17-21.

8. Климушкин В. А. К проблеме определения качества оказания юридической помощи / В. А. Климушкин // Ученые труды Российской академии адвокатуры и нотариата. - 2012. - № 3. - С. 25-33.

9. Чашин А. Н. Стандарты качества юридических услуг / А. Н. Чашин. - М. : Дело и Сервис, 2013. - 96 с.

10. Чумакова О. В. О возможности применения в Российской Федерации зарубежного опыта по обеспечению качества бесплатной юридической помощи / О. В. Чумакова / / Мониторинг правоприменения. 2017. - № 2 (23). - C. 19-24.

11. Хворов А. В. Новые стандарты юридической помощи / А. В. Хворов // Вестник Тамбовского университета. Серия «Гуманитарные науки». - 2009. - № 12 (80). - С. 387-391.

12. Накушнова Е. В. Критерии качества правовых услуг / Е. В. Накушнова // Современное право. 2013. - № 9. - C. 46-51.

13. Юрьев С. С. К проблеме эфффективности юридических услуг / С. С. Юрьев / / Вопросы российского и международного права. - 2012. - № 5-6. - С. 37-46.

14. Ситдикова Л. Б. Критерии оценки качества консультационных услуг / Л. Б. Ситдикова / / Современное право. - 2007. - № 1. - С. 14-16.

\section{REFERENCES}

1. Vatolkina N. Sh. Systematization of the approaches to «service quality» definition. Izvestiya Dal'nevostochnogo federal' nogo universiteta. Ekonomika i upravlenie = The bulletin of the Far Eastern Federal University. Economics and Management, 2012, no. 4 (64), pp. 82-93. (In Russian).

2. Abramov S. S. Estimation of quality of services considering a consumer's view. Vestnik Adygeiskogo gosudarstvennogo universiteta. Seriya 5, Ekonomika $=$ The Bulletin of the Adyghe State University, Series 5, Economics, 2011, no. 1, pp. 215-221. (In Russian).

3. Lovelock Christopher. Services Marketing: People, Technology, Strategy. Prentice Hall, 2000. 717 p. (Russ. ed.: Lovelock Ch. Marketing uslug: personal, tekhnologii, strategii. Moscow, Vil'yams Publ., 2005. 982 p.).

4. Berlin E. M. Legislative Regulation of the Quality of Legal Services. Pravo i ekonomika = Law and Economics, 2002, no. 5, pp. 23-28. (In Russian).

5. Barshchevskii M. Yu. Advokatskaya etika [Legal Ethics]. Moscow, Profobrazovanie Publ., 2000. 312 p.

6. Kratenko M. V. Accessibility of Legal Services and Certain Kinds of Its Contracts. Problemy formirovaniya pravovogo sotsial'nogo gosudarstva v sovremennoi Rossii. Materialy 9-i Vserossiiskoi nauchno-prakticheskoi 
konferentsii, Novosibirsk, 30 oktyabrya 2013 g. [lssues of Development of Rule-of-Law and Social Welfare State in Contemporary Russia. Materials of $9^{\text {th }}$ Russian National Research-to-Practice Conference, Novosibirsk, 30 October 2013]. Novosibirsk State Agrarian University Publ., 2013, pp. 117-121. (In Russian).

7. Gavrilov S. N. On the quality of legal aid in legal profession. Yurist"-Pravoved" = Jurist-Pravoved, 2007, no. 6, pp. 17-21. (In Russian).

8. Klimushkin V. A. A problem of determination the quality of legal aid. Uchenye trudy Rossiiskoi akademii advokatury i notariata = Scientific Works of the Russian Academy of Advocacy and Notary, 2012, no. 3, pp. 25-33. (In Russian).

9. Chashin A. N. Standarty kachestva yuridicheskikh uslug [Standards of Legal Services Quality]. Moscow, Delo i Servis Publ., 2013.96 p.

10. Chumakova O. V. On the feasibility of using foreign experience in ensuring the quality of free legal aid in the Russian Federation. Monitoring pravoprimeneniya = The Monitoring of Law Enforcement Journal, 2017, no. 2 (23), pp. 19-24. (In Russian).

11. Hvorov A. V. New standards of legal aid. Vestnik Tambovskogo universiteta. Seriya "Gumanitarnye nauki» = Tambov University Review. Series Humanities, 2009, no. 12 (80), pp. 387-391. (In Russian).

12. Nakushnova Ye. V. The Criteria of Quality Legal Services. Sovremennoe pravo= Modern Law, 2013, no. 9, pp. 46-51. (In Russian).

13. Yur'ev S. S. On the problem of the efficiency of legal services. Voprosy rossiiskogo i mezhdunarodnogo prava $=$ Matters of Russian and International Law, 2012, no. 5-6, pp. 37-46. (In Russian).

14. Sitdikova L. B. Criteria of Assessment of Advisory Services Quality. Sovremennoe pravo = Modern Law, 2007, no. 1, pp. 14-16. (In Russian).

\section{Информация об авторах}

Полякова НинаВладимировна - доктор экономических наук, профрессор, кафедра менеджмента, маркетинга и сервиса, Байкальский государственный университет, 664003, г. Иркутск, ул. Ленина, 11, e-mail: PolyakovaNV@bgu.ru.

Поляков Владимир Владимирович - кандидат экономических наук, доцент, кафедра менеджмента, маркетинга и сервиса, Байкальский государственный университет, 664003, г. Иркутск, ул. Ленина, 11, e-mail: vla88701858@yandex.ru.

БарановаЮлия Олеговна - аспирант, кафедра менеджмента, маркетинга и сервиса, Байкальский государственный университет, 664003, г. Иркутск, ул. Ленина, 11, e-mail: yulishka.92@mail.ru.

\section{Для цитирования}

Полякова Н. В. Критерии качества юридических услуг, предоставляемых гражданам / Н.В.Полякова, В.В.Поляков, Ю.О.Баранова // Известия Байкальского государственного университета. - 2017. - T. 27, № 4. - C. 468-477. - DOI: $10.17150 / 2500-2759.2017 .27(4) .468-477$.

\section{Authors}

Nina V. Polyakova - DSc in Economics, Professor, Department of Management, Marketing and Service, Baikal State University, 11 Lenin St., 664003, Irkutsk, Russian Federation, e-mail: PolyakovaNV@bgu.ru.

Vladimir V. Polyakov - PhD in Economics, Associate Professor, Department of Management, Marketing and Service, Baikal State University, 11 Lenin St., 664003, Irkutsk, Russian Federation, e-mail: vla88701858@yandex.ru.

Julia O. Baranova - PhD Student, Department of Management, Marketing and Service, Baikal State University, 11 Lenin St., 664003, Irkutsk, Russian Federation, e-mail: yulishka.92@mail.ru.

\section{For citation}

Polyakova N. V., Polyakov V. V., Baranova Ju. O. Criteria for the Quality of Legal Services Provided to Citizens. Izvestiya Baykal'skogo gosudarstvennogo universiteta $=$ Bulletin of Baikal State University, 2017, vol. 27, no. 4, pp. 468-477. DOI: 10.17150/25002759.2017.27(4).468-477. (In Russian). 